\title{
Repercussions of behavior of cooperative teacher's on health and attractiveness of Tunisian student teachers
}

\author{
Wadii Zayed $^{1 \mathrm{ABCD}}$, Naila Bali ${ }^{2 \mathrm{BC}}$, Nizar Souissi ${ }^{3 \mathrm{AD}}$ \\ ${ }^{1}$ High Institute of Sport and Physical Education, University of Gafsa, Gafsa, Tunisia \\ ${ }^{2.3}$ High Institute of Sport and Physical Education, University of Manouba, Manouba, Tunisia
}

Authors' Contribution: A - Study design; B - Data collection; C - Statistical analysis; D - Manuscript Preparation; E - Funds Collection.

\begin{abstract}
Purpose: $\quad$ This study was to explore the repercussions of the cooperative teacher's (CT) behavior on health and attractiveness of Physical Education student teachers (PE-ST) believed to be important for a successful preparatory traineeship and training device in the professional life. The CT is considered a person of alternation between academia and training, contributing to the formation by advice and support. The Cooperative Teacher's must have a style; develop a training contract, master interview techniques and make evaluation. However, questions remain as to how well Higher Education Institutions prepare the Student Teachers to meet the challenges and requirement of work environments.

Material: $\quad$ Data were collected with 302 student teachers (202 males and 100 females) before professional training. A descriptive/exploratory methodology based on a questionnaire consisting of eighteen questions was used. The value of Cronbach alpha index is 0.857 .

Results: $\quad$ globally supported the hypotheses. Male and female student teachers in the internship shared several perceptions. However, significant differences emerged. Student teachers perception of CT behavior and supports developed relatively professional skills, personal life as well as the feeling of discomfort which can lead to work stoppage. However, the repercussion of CT behavior on health and attractiveness was significant. The negative relationship between actors in the in professional life and several aspects of CT behavior are provided. In addition, data are provided indicating that overall there are more similarities than differences between male and female student teachers students over a response number. Data also suggest that females who participate in the internship may be at risk for discomfort and anxiety problems.

Conclusions: This study will encourage Teacher's to reflect on their own behaviors, support practices and to include them in the process of educational development.

Keywords: Physical Education, traineeship, tutor, accompanying practices, discomfort.
\end{abstract}

\section{Introduction}

Studies on professional skills have received significant attention in the last decade. However, questions remain as to how well Higher Education Institutions prepare the Student Teachers (PE-STs) to meet the challenges and requirement of work environments $[1,2]$. Concerns remain that the accompaniment practices may not be equipping (PE-STs) with the key skills needed to confront real teaching problems [3]. Perez-Roux [4] and Bali [5] claimed that the cooperative Teachers (CT) are contributing to their integration in the professional life. The CT is considered a person of alternation between academia and training, contributing to the formation by advice and support $[6,7]$. CT must have a style; develop a training contract, master interview techniques and make evaluation [8]. This is corroborated by a number of studies in different disciplines. For instance, Mella [9] and Hasan [10] found that the accompaniment is a function of following a PE-ST and to walk with them for a period in order to exchange about them action, thinking together and evaluate it. Kosnik [11] found that internship can be a stressful moment and anxiety provoking. This is affirmed by Desbiens et al. [12] that during this time the PE-STs will attempt to meet unrealistic expectations. This experience may become a source of discomfort, exhaustion and

(C) Wadii Zayed, Naila Bali, Nizar Souissi , 2018

doi:10.15561/20755279.2018.0208 confusion $[11,13]$. It is against this backdrop that carlier [14] averred that the current context of education in what will immerse future graduates is certainly not positive.

Thus, university education and the workplace training need to identify different working patterns that CT might engage in and ensure that they possess employability skills that meet the employer's requirements [2]. Boutin and Camaraire [15] claimed that HEIs should develop the criteria for selecting EA. Faingold [16] found that the important points of training are the quality of discussion, listening, the type of questions and the relationship between PE-ST and CT. However, Boutet [17] opined that the characteristics of an effective EA: experience, self-confidence, openness to theoretical contributions and reflection, coherence and acceptance to be questioned. Further, in the case of interaction between PE-ST and CT in post-lesson interviews, Trohel et al. [18] described each actor involved in these interactions. They noticed that the CT is not trained in the role of tutor; they act according to their professional experience in teaching physical education. Beau-Antoine and al. [19], also, studied the characteristics of the CT's professional activity and try to identify the difficulties encountered during PE-ST supervision. They found that tutoring is a difficult function to perform because the CT is not well trained. Carlier [8] assumed that the CT and PE-ST exchange academic and practical knowledge to guide the verbalization of PE-ST'S 
action by asking questions that they have put in place. He suggests that CTs recognize the existence of two types of knowledge and try to exploit them optimally. This is proved by Vandercleyen and al. [20] that the success of training depends on the type of intervention with PE-ST. They highlight the dual role of EA, to be able to explain their own pedagogical concepts to PE-ST and help them to clarify their thoughts, actions and decisions. Boutet and Pharand [21] noted that PE-ST want to be guided. They want to take the initiative and accept critique. Rayou and Ria [22] state that PE-ST has a clear awareness of the reasons of failure or success in their interventions.

In Tunisia, university aims is to help PE-STs to integrate professional life. We answered through this research the following questions are: the behaviors of the CT transformed in to discomfort? What repercussions do they have PE-STs?

\section{Material and methods}

\section{Participants}

The participants in this study are 302 PE-STs (202 males and 100 females) from total 314 PE-STs studying in the Higher Institute of Sport and Physical Education (ISSEP) Tunis (there are only 3 ISSEP, in Tunisia each has their own teaching practice modality). All participants in this study were volunteers'. They were recruited from a single Higher Institute of Sport (Tunis). The group of participants consisted of the third year PE-ST. All were aged between ( $22 \pm 1$ years) registered in an introductory practicum to professional training in Tunisia (introductory practicum applied to pedagogy), that is ended, in the last year, by the Fundamental License of Physical Education. This activity has serves as an introduction to professional life. The activity lasts two semesters: four hours per week on Tuesday or Thursday for a cumulative total time of 116 hours of teaching. Participants are not paid to participate in the research. They were not informed about the purpose and conception of the research.

Table 1: Sample of Tunisian PE-ST

\begin{tabular}{ll}
\hline Characteristics & PE-ST \\
\hline Questioning & 302 \\
Males questioned & 202 \\
Females questioned & 100 \\
Aged & Between 20 and 23 years \\
Level of study & BAC +3 \\
\hline
\end{tabular}

Three main reasons justified the choice of this sample. First, this study is part of the professional training of PEST. The CT is considered an person intermediate between the university and the training environment, which will allow us to recognize the nature of PE-ST preoccupation of accompaniment practice of CT. Second, there is a social difference between the academic and the professional. This allowed us to hypothesize that this difference can be translated into shock and preoccupation. Third, this study is part of the academic program, which enabled us to hypothesize the preoccupation between PE-ST and CT's accompaniment practices to spoil PE-ST learning. Our work sample meets these three parameters as indicated in the table $\mathrm{N}^{\circ} 1$ below.

\section{Measures}

This quantitative study explored the PE-STs conceptions about professional training. It identified the repercussions of the cooperative teacher's behavior on health and attractiveness of student teachers. We used the questionnaire consisting of two dimensions in which we have grouped the different types of questions to clarify and give PE-STs the opportunity to share their preoccupation such as CT behavior repercussions. The questions focus on the preoccupation of PE-STs of the CT accompaniment practices after the internship. Participants responded to 18 items on a 4-point Likert-type scale ranging from 4 from 1 (never) to 4 (usually) that were tested in a pilot study. Following the quantitative responses obtained from the questionnaire, we analyzed these data using the statistical software SPSS 16 (Statistical Package for social science).

\section{Procedures}

First of all, the permission was granted by the Director of ISSEP Tunis and teachers to realize the current study. Then, the researcher collected the PE-STs, explained the stages of the study and the different questions in the questionnaire for PE-STs, oversaw the privacy and uniqueness of answers. In this study, we presented to the PE-STs the different steps of this research to know the phases of the questionnaire. PE-STs were not informed of the purpose and design of the research. PE-STs are questioned by allowing them the freedom to respond, they can express themselves at their ease. Our data was analyzed using a statistic constant.

\section{Statistical Analysis}

Analyses were performed using statistical software SPSS 16 (Statistical Package for social science) program. The following variables were calculated using descriptive statistic: frequencies, percentages, and Cronbach alpha index. Assessment of statistical significance between male and female student teachers was performed using a Chi-square. Correlation between CT behavior on health and attractiveness of PE-ST was applied. A p value less than 0.05 was considered statistically significant.

\section{Result}

\section{The CT behavior}

Eight items emerged from the data collected and were illustrated in Table 2: Item 1) CT gets angry, Item 2) CT verbally assaults PE-ST, Item 3) CT insults PE-ST for the mistakes, Item 4) CT does not behave the same attitude with PE-ST, Item 5) CT sends a way that demoralize, Item 6) CT does not congratulate PE-ST, Item 7) CT emits PEST negative remarks, Item 8) CT undervalue the work of PE-ST.

The dimension under the "behavior" of CT includes eight items: Item 1: "CT gets angry" (S/U =32.8/ 8.9 $\%$; Item 2: "CT verbally assaults $P E-S T$ " (S/U =16.6/6 $\%$ ); Item 3: "CT insults PE-ST for the mistakes" (S/U $=20.2 / 16.6 \%$ ); Item 4: "CT does not behave the same attitude with PE-ST" ( $\mathrm{S} / \mathrm{U}=15.2 / 10.9 \%)$; Item 5: "CT 
sends a way that demoralize" ( $\mathrm{S} / \mathrm{U}=25.8 / 11.6 \%)$; Item 6: " CT does not congratulate PE-ST" (S/U =27.2 /15.6 $\%$ ); Item 7 "CT emits PE-ST negative remarks" (S/U $=35.8 / 21.9 \%$ ); Item 8: "CT undervalue the work of PE$S T "(\mathrm{~S} / \mathrm{U}=32.8 / 12.9 \%)$.

No significant gender differences were found for $C T$ gets angry (X2 $=0.21$ to $P=9,728)$, CT verbally assaults $P E-S T(\mathrm{X} 2=0.341, P=3.346), C T$ insults $P E-S T$ for the mistakes ( $\mathrm{X} 2=0.627, P=1.747)$, CT does not behave the same attitude with PE-ST (X2 = 0.766, $P=1.145), C T$ sends $a$ way that demoralize (X2 $=0.991, P=0.108), C T$ does not congratulate PE-ST (X2 = 0.637, $P=1.700), C T$ emits $P E-S T$ negative remarks ( $\mathrm{X} 2=0.334, P=3.403)$ and CT undervalue the work of PE-ST (X2 =0.097, $P=$ 6.331).

\section{The CT behavior repercussions}

- $\quad$ Life repercussions (LR)

Three items emerged from the data collected and were illustrated in Table 3: Item 1) repercussions of the problems on your personal life, Item 2) Anxiety relatives about your problems in training, item 3) At night, your work prevents you from sleeping.

The «PE-ST life repercussions" includes three items: Item 1: "repercussions of the problems on your personal life" (Sometimes/Usually=25.5/ 16.2\%); Item 2: "Anxiety relatives about your problems in training" $(\mathrm{S} / \mathrm{U}=30.8$ / $13.9 \%$ ); Item 3: "At night, your work prevents you from sleeping” ( $\mathrm{S} / \mathrm{U}=34.1 / 24.2 \%)$.

Data supported the positive correlation between all the CT's behavior and Life repercussions. However, "the work prevents PE-ST from sleeping" was not significantly associated with "the differentiation of CT behavior from PE-STs” ( $r=0.022 ; \mathrm{p}=0.353$ ) (see Table 4 for details).
- Health repercussions (HR)

Three items emerged from the data collected and were illustrated in Table 4: item 1) consult a doctor, item 2) a psychologist, item 3) an unanticipated leave.

The «PE-ST Health repercussions" includes Three items: Item 1: "consult a doctor" $(\mathrm{S} / \mathrm{U}=8.3 / 4.6 \%)$; Item 2: "Consult a psychologist" ( $\mathrm{S} / \mathrm{U}=7.6 / 5.6 \%)$; Item 3: «An unanticipated leave" ( $\mathrm{S} / \mathrm{U}=20.2 / 16.6 \%)$.

No significant gender differences were found for PE-ST consult a doctor $\left(\mathrm{X}^{2}=0.658, \mathrm{P}=1.606\right), P E-S T$ a psychologist $\left(\mathrm{X}^{2}=0.415, \mathrm{P}=2.854\right.$. $)$ and an unanticipated leave $\left(\mathrm{X}^{2}=0.389, \mathrm{P}=3.016\right.$. $)$.

Correlations supported the positive, significant relationship between all the CT behavior and the $P E$ ST Health. However, "the consult a doctor" was not significantly associated with CT demoralizes $(r=0.093$; $\mathrm{p}=0.053$ ) and consult a psychologist was only not significantly associated with the negative remarks emitted by CT ( $\mathrm{r}=0.44 ; \mathrm{p}=0.221)$. An unanticipated leave was not significantly related with $\mathrm{CT}$ congratulations; negative remarks and the differentiation of behavior from PE-STs (see Table 6 for details).

- The attractiveness of the profession repercussions (AR)

Four items were identified from the data collected and illustrated in Table 7: item 1) Having considered another professional orientation, item 2) Having considered a work stoppage, item 3) The feeling of strong anger, the urge to cry, item 4) Having thought to be in a bad situation.

The " The attractiveness of the profession repercussions " of PE-ST from CT includes five items: Item 1: "Consider another professional orientation " $(\mathrm{S} / \mathrm{U}=13.9$ /8.6\%); Item 2: “ Having considered a work

Table 2: The different items of the CT behavior

\begin{tabular}{lllllll}
\hline Items & $\begin{array}{l}\text { Never } \\
(\%)\end{array}$ & $\begin{array}{l}\text { Rarely } \\
\text { (\%) }\end{array}$ & $\begin{array}{l}\text { Sometimes } \\
(\%)\end{array}$ & $\begin{array}{l}\text { Usually } \\
\text { (\%) }\end{array}$ & X $^{\mathbf{2}}$ & P \\
\hline 1. CT gets angry & 37.7 & 20.5 & 32.8 & 8.9 & 0.21 & 9.728 \\
2. CT verbally assaults PE-ST & 63.2 & 14.2 & 16.6 & 6 & 0.341 & 3. \\
& & & & & 346 \\
3. CT insults PE-ST for the mistakes & 32.8 & 30.5 & 20.2 & 16.6 & 0.627 & 1.747 \\
4. CT don't behave the same attitude with PE-ST & 49.3 & 23.8 & 15.9 & 10.9 & 0.766 & 1.145 \\
5. CT sends a way that demoralizes PE-ST & 33.4 & 29.1 & 25.8 & 11.6 & 0.991 & 0.108 \\
6. CT does not congratulate PE-ST & 32.8 & 24.5 & 27.2 & 15.6 & 0.637 & 1.700 \\
7. CT emits negative remarks & 14.9 & 27.5 & 35.8 & 21.9 & 0.334 & 3.403 \\
8. CT undervalue the work of PE-ST & 32.5 & 21.9 & 32.8 & & 0.097 & 6. \\
\hline
\end{tabular}

Table 3. The different items of life repercussions

\begin{tabular}{lllllll}
\hline Items & $\begin{array}{l}\text { Never } \\
(\%)\end{array}$ & $\begin{array}{l}\text { Rarely } \\
(\%)\end{array}$ & $\begin{array}{l}\text { Sometimes } \\
(\%)\end{array}$ & $\begin{array}{l}\text { Usually } \\
\text { (\%) }\end{array}$ & $\mathbf{X}^{\mathbf{2}}$ & $\mathbf{P}$ \\
\hline $\begin{array}{l}\text { 1. Repercussions of the problems on your } \\
\text { personal life }\end{array}$ & 33.1 & 25.2 & 25.5 & 16.2 & 0.438 & 2.712 \\
$\begin{array}{l}\text { 2. Anxiety relatives about your problems in } \\
\text { training }\end{array}$ & 27.5 & 27.8 & 30.8 & 13.9 & 0.106 & 6.108 \\
3. At night, your work prevents you from sleeping & 19.2 & 22.5 & 34.1 & 24.2 & 0.019 & 9.926 \\
\hline
\end{tabular}


Table 4. Correlations between the CT behavior and the life repercussions

\begin{tabular}{|c|c|c|c|c|c|c|c|c|c|}
\hline Items & Correlation & Behvr 1 & $\begin{array}{l}\text { Behvr } \\
2\end{array}$ & Behvr 3 & Behvr 4 & Behvr 5 & Behvr 6 & Behvr 7 & Behvr 8 \\
\hline \multirow{3}{*}{ LR 1} & $\begin{array}{l}\text { Pearson } \\
\text { Correlation }\end{array}$ & ,311 & ,196** & ,279** & ,228** &, $173^{* *}$ & ,219** &, $134^{* *}$ &, $155^{* *}$ \\
\hline & Sig. (1-tailed) & ,000 & ,000 & ,000 & ,000 & ,001 & ,000 & 010 & ,003 \\
\hline & $\mathrm{N}$ & 302 & 302 & 302 & 302 & 302 & 302 & 302 & 302 \\
\hline \multirow{3}{*}{ LR 2} & $\begin{array}{l}\text { Pearson } \\
\text { Correlation }\end{array}$ &, $170^{* *}$ &, $148^{* *}$ &, $226^{* *}$ &, $267^{* *}$ & ,208** &, $193^{* *}$ &, $151^{* *}$ &, $225^{* *}$ \\
\hline & Sig. (1-tailed) & ,001 & ,005 & ,000 & ,000 & ,000 & ,000 & ,004 & ,000 \\
\hline & $\mathrm{N}$ & 302 & 302 & 302 & 302 & 302 & 302 & 302 & 302 \\
\hline \multirow{3}{*}{ LR 3} & $\begin{array}{l}\text { Pearson } \\
\text { Correlation }\end{array}$ & ,190** & $142^{* *}$ & ,301 &, $283^{* *}$ & , $188^{* *}$ &, $251^{* *}$ & ,229** & ,022 \\
\hline & Sig. (1-tailed) & ,000 & ,007 & ,000 & ,000 & ,001 & ,000 & ,000 & 353 \\
\hline & $\mathrm{N}$ & 302 & 302 & 302 & 302 & 302 & 302 & 302 & 302 \\
\hline
\end{tabular}

**. Correlation is significant at the 0.01 level (1-tailed).

*. Correlation is significant at the 0.05 level (1-tailed).

Table 5. The different items of health repercussions

\begin{tabular}{lllllll}
\hline Items & $\begin{array}{l}\text { Never } \\
(\%)\end{array}$ & $\begin{array}{l}\text { Rarely } \\
(\mathbf{\%})\end{array}$ & $\begin{array}{l}\text { Sometimes } \\
(\%)\end{array}$ & $\begin{array}{l}\text { Usually } \\
(\%)\end{array}$ & $\mathbf{X}^{\mathbf{2}}$ & P \\
\hline 1. Consult a doctor & 74.8 & 12.3 & 8.3 & 4.6 & 0.658 & 1.606 \\
2. Consult a psychologist & 77.5 & 9.3 & 7.6 & 5.6 & 0.415 & 2.854 \\
3. An unanticipated leave & 69.2 & 18.2 & 9.9 & 2.6 & 0.389 & 3.016 \\
\hline
\end{tabular}

Table 6. Correlations between the CT behavior and the PE-ST Health repercussions

\begin{tabular}{llllllllll}
\hline Items & Correlation & Behvr 1 & Behvr 2 & Behvr 3 & Behvr 4 & Behvr 5 & Behvr 6 & Behvr 7 & Behvr 8 \\
\hline \multirow{3}{*}{ HR 1 } & Pearson Correlation &, $099^{*}$ &, $104^{*}$ &, $150^{* *}$ &, $135^{* *}$ &, $132^{*}$ &, $166^{* *}$ &, $245^{* *}$ &, 093 \\
& Sig. (1-tailed) &, 042 &, 036 &, 005 &, 009 &, 011 &, 002 &, 000 &, 053 \\
& $\mathrm{~N}$ & 302 & 302 & 302 & 302 & 302 & 302 & 302 & 302 \\
& Pearson Correlation &, $116^{*}$ &, $170^{* *}$ &, 044 &, $197^{* *}$ &, $200^{* *}$ &, $272^{* *}$ &, $398^{* *}$ &, $233^{* *}$ \\
\multirow{2}{*}{ HR 1 } & Sig. (1-tailed) &, 022 &, 002 &, 221 &, 000 &, 000 &, 000 &, 000 &, 000 \\
& $\mathrm{~N}$ & 302 & 302 & 302 & 302 & 302 & 302 & 302 & 302 \\
& Pearson Correlation &, 077 &, 081 &, 070 &, $108^{*}$ &, $224^{* *}$ &, $187^{* *}$ &, $313^{* *}$ &, 054 \\
\multirow{4}{*}{ HR 3 } & Sig. (1-tailed) &, 091 &, 079 &, 111 &, 030 &, 000 &, 001 &, 000 &, 176 \\
& $\mathrm{~N}$ & 302 & 302 & 302 & 302 & 302 & 302 & 302 & 302 \\
\hline
\end{tabular}

**. Correlation is significant at the 0.01 level (1-tailed).

*. Correlation is significant at the 0.05 level (1-tailed).

Table 7. The attractiveness of the profession repercussions

\begin{tabular}{|c|c|c|c|c|c|c|}
\hline Items & $\begin{array}{l}\text { Never } \\
(\%)\end{array}$ & $\begin{array}{l}\text { Rarely } \\
(\%)\end{array}$ & $\begin{array}{l}\text { Sometimes } \\
(\%)\end{array}$ & $\begin{array}{l}\text { Usually } \\
(\%)\end{array}$ & $\mathbf{X}^{2}$ & $\mathbf{P}$ \\
\hline 1. Consider another professional orientation & 54.6 & 22.8 & 13.9 & 8.6 & 0.866 & 0.732 \\
\hline 2. Consider stopping work in an internship & 58.9 & 20.5 & 15.9 & 4.6 & 0.227 & 4.339 \\
\hline 3. Have The feeling of strong anger, the urge to cry & 31.1 & 22.2 & 32.1 & 14.6 & 0.000 & 22.00 \\
\hline $\begin{array}{l}\text { 4. Have thought to be in a bad situation at the } \\
\text { internship }\end{array}$ & 23.2 & 30.5 & 32.5 & 13.9 & 0.909 & 0.544 \\
\hline
\end{tabular}

stoppage " ( $\mathrm{S} / \mathrm{U}=15.9 / 4.6 \%)$; Item 3: " The feeling of strong anger, the urge to cry" ( $\mathrm{S} / \mathrm{U}=32.1 / 14.6 \%)$; Item 4: " Having thought to be in a bad situation " $(\mathrm{S} / \mathrm{U}=32.5$ $/ 13.9 \%)$.

Significant gender differences were also found for $P E$ ST feeling of strong anger, the urge to cry $\left(\mathrm{X}^{2}=0.000\right.$, $\mathrm{P}=22.000$; females stronger). No significant gender differences were found for PE-ST Consider another professional orientation ( $\mathrm{X} 2=0.866, P=0.732)$, having considered a work stoppage (X2 =0.227, $P=4.339), C T$ remains in the classroom $(\mathrm{X} 2=0.501, P=2.362)$, having thought to be in a bad situation $\left(\mathrm{X}^{2}=0.909, \mathrm{P}=0.544\right)$.

Correlations supported the positive, significant relationship between all the CT behavior and the 
Table 8. Correlations between the CT behavior and the PE-ST attractiveness of the profession repercussions

\begin{tabular}{|c|c|c|c|c|c|c|c|c|c|}
\hline Items & Correlation & Behvr 1 & Behvr 2 & Behvr 3 & Behvr 4 & Behvr 5 & Behvr 6 & Behvr 7 & Behvr 8 \\
\hline \multirow{3}{*}{ AR 1} & $\begin{array}{l}\text { Pearson } \\
\text { Correlation }\end{array}$ &, $117^{*}$ &, $148^{* *}$ & ,048 & ,087 & ,004 & ,088 & ,044 & ,099* \\
\hline & Sig. (1-tailed) & ,021 & ,005 & 203 & ,067 & 471 & ,064 & ,223 & ,043 \\
\hline & $\mathrm{N}$ & 302 & 302 & 302 & 302 & 302 & 302 & 302 & 302 \\
\hline \multirow{3}{*}{ RETRq8 } & $\begin{array}{l}\text { Pearson } \\
\text { Correlation }\end{array}$ &, $306^{* *}$ &, $275^{* *}$ & $197^{* *}$ &, $361^{* *}$ &, $225^{* *}$ &, $283^{* *}$ &, $266^{* *}$ &, $230^{* *}$ \\
\hline & Sig. (1-tailed) & ,000 & ,000 & ,000 & ,000 & ,000 & ,000 & ,000 & ,000 \\
\hline & $\mathrm{N}$ & 302 & 302 & 302 & 302 & 302 & 302 & 302 & 302 \\
\hline \multirow{3}{*}{ RETRq9 } & $\begin{array}{l}\text { Pearson } \\
\text { Correlation }\end{array}$ &, $408^{* *}$ &, $354^{* *}$ &, $293^{* *}$ &, $364^{* *}$ &, $208^{* *}$ &, $358^{* *}$ &, $348^{* *}$ &, $212^{* *}$ \\
\hline & Sig. (1-tailed) & ,000 & ,000 & ,000 & ,000 & ,000 & ,000 & ,000 & ,000 \\
\hline & $\mathrm{N}$ & 302 & 302 & 302 & 302 & 302 & 302 & 302 & 302 \\
\hline \multirow{3}{*}{ RETRq10 } & $\begin{array}{l}\text { Pearson } \\
\text { Correlation }\end{array}$ &, $441^{* *}$ &, $413^{* *}$ &, $337^{* *}$ &, $437^{* *}$ &, $366^{* *}$ &, $474^{* *}$ & ,399** &, $242^{* *}$ \\
\hline & Sig. (1-tailed) & ,000 & ,000 & ,000 & ,000 & ,000 & ,000 & ,000 & ,000 \\
\hline & $\mathrm{N}$ & 302 & 302 & 302 & 302 & 302 & 302 & 302 & 302 \\
\hline
\end{tabular}

**. Correlation is significant at the 0.01 level (1-tailed).

*. Correlation is significant at the 0.05 level (1-tailed).

attractiveness of the profession. However, having Considered another professional orientation was only significantly associated with CT demoralizes $(r=0.117$; $\mathrm{p}=0.021)$, congratulations $(\mathrm{r}=0.148 ; \mathrm{p}=0.005)$ and the differentiation between the CT's and the PE-STs behavior $(\mathrm{r}=0.099 ; \mathrm{p}=0.043)$ (see Table 8 for details).

\section{Discussion}

The role of CT is to provide a training quality in terms of accompaniment for students trainees that meets the challenges and requirements of work environment as a whole, which have not been recognized. Thus, the purpose of this research was to identify and analyze the repercussions of CT behavior on health and attractiveness of student teachers (PE-STs) (assiduity, attitude and valorization) which are believed to be important for a successful Tutoring and training device in the workplace.

According to our results, Paquay [23] suggests a personal and relational development between CT and PE-STs. He proposed to do courses or workshops and developing skills to express themselves, communicate, analyze relationships, develop listening, to lead a group and improve self-confidence. Buyse et al. [24] emphasize the importance of establishing a positive relationship between teacher and students in the classroom. According to Hamre and Pianta [25], PE-ST must make efforts to stabilize the classroom climate. They add that the teacher must establish a relationship of trust with students by using effective classroom management practices. At the welcome of the PE-STs, Zayed and al. [26] opined that the major concern of CTs is the PE-ST behavior. Monfette and Grenier [27] suggest that we let PE-ST take charge of groups, some CT offered self-development opportunities to PE-STs by helping them to develop their independence and their ability to adapt.
Our results showed a discomfort, stress, distress, exhaustion in the workplace. In a period of professional integration, Ndoreraho and Martineau [28] report that stress in work environment affects the interest of PEST in the teaching profession. Gaudreau et al. [29] adds that inappropriate behavior in the work context has an effect on the teacher's effectiveness and makes him vulnerable to stress and burnout. In this sense, Gilbert and al. [30] suggests understanding the various origins of this situation. Suffering indices are many; they are the cause of the abandonment of the profession. Distress and exhaustion are indicators of the pain experienced by teachers. Houlfort \& Sauvé [31] found that depression and burnout are perceived as a problem of the organizational environment. This is shown by Doudin [32] who proved the presence of the problem of stress and exhaustion. He confirms the presence of distress among teachers in Europe. Doudin [32] adds that the European teachers are most affected by stress at work. He concludes that depression is a deterioration of the well-being of the individual. However, Gilbert [30] cleaned that violence is the cause of the suffering of teachers in the workplace. She can take a physical, verbal form of the order of intimidation. She confirms that teachers in Quebec (17.1\%) are the second most professions affected by violence in the workplace.

Our results, Also, showed health problems among teachers. Bauer and al. [33] noted that in Germany there are healths problems among teachers and that psychological disorders are the major cause of abandonment. They confirm that teachers play an important role in the training of students. They think that the profession is far from being recognized by society. In this sense, Mukamurera [34] adds that the teaching profession suffers from a lack of political and social awareness.

The attractiveness of the profession can be provided by 
CT behavior. Our results demonstrate that the repercussion of CT behavior and attractiveness was significant. Early in his career, Mukamurera [34] mentioned that the percentage of dropout professional teachers is worrying. He says that, in the first five years, one in five teachers give up practice and about $43 \%$ consider the option to leave teaching. According to Ingersoll and Smith [35], in the United States, the percentage of dropout is 40 to $50 \%$ among new teachers. Half of the teachers leave the teaching profession in the first years of teaching. Parmentier [36] suggests valuing PE-ST in their interventions. They must express themselves by attaching the content of the training to their lived experiences or their knowledge. They will either retain it or integrate it. Otherwise, they will just pile up knowledge they will quickly forget. If we want, the PE-ST to express themselves, these interventions must be lived not as a constraint or a judgment but as a valorization of their experience. This valorization intervenes from the beginning of the internship by the interest that CT carries with the PE-ST, and lasts throughout the internship, by the attentive reaction of their interventions. Monfette \& Grenier [27] suggest letting their trainees take charge of the groups, they confirm that some CTs have offered selfdevelopment opportunities to their trainees by helping them to develop their autonomy and their ability to adapt.

In training, the PE-ST is motivated if he becomes a real actor by feeling valued and secure. The CT must secure and support the PE-ST, both materially and psychologically. Rajuana et al. [37] opined to introduce trainees to students and to give them as much information as possible about the program and materials. In this sense, Gold [38] offered two categories of support: support for teaching (pedagogical support) and psychological support. Teaching support consist of assisting with the acquisition of knowledge, skills and strategies for success in the school. This support can consist of information support (advice, information) and evaluative feedback (feedback). Psychological support comes from a humanistic perspective. It includes both emotional support (listening, encouragement and trust), evaluative support (need to be reassured and confirmed) and support for identity development (selfconfidence, sense of effectiveness, positive self-esteem and stress management). Psychological support can help ES to develop resilience to difficult career conditions (insecurity, heavy work, difficult group-classes), to develop a positive self-image and to maintain a positive relationship with the profession.

\section{Conclusion}

The questions addressed in this study will encourage CT to reflect on their own behaviors, support practices and to include them in the process of accompaniment of PE-STs. Our results reflect the views of all the population of PE-ST exercising their traineeship in schools of Tunis. In light of our results, it is possible to make a statement concerning CT accompaniment practices and preoccupations of PE-ST. We are far from an ideal accompaniment situation and PE-ST problems that life must draw the attention of the priority of the internship responsible. Furthermore, the hypothesis is verified: CT accompaniment practices can be characterized by a high variability, namely behavior on a scale Frequency converter.

In Tunisia, we saw that accompaniment practices offer relatively favorable climate training. This statement should hold the attention of CT, supervisors, university teachers and people in charge of training, and get them to think a light of PE-STs preoccupation. So accompaniment practices are called for new developments in the near future. Data from PE-STs provide lighting and additional lines of investigation to improve accompaniment practices.

\section{Conflict of interests}

The authors declare that there is no conflict of interests.

\section{References}

1. Pennaforte AP. Organizational supports and individuals commitments through work integrated learning. Higher Education, Skills and Work-Based Learning, 2016; 6(1): 8999.

2. Perera S, Perera S, Babatunde SO, Babatunde SO, Pearson J, Pearson J, Ekundayo D. Professional competency-based analysis of continuing tensions between education and training in higher education. Higher Education, Skills and Work-Based Learning, 2017; 7(1): 92-111.

3. Amamou S. The perception of self-efficacy in classroom management by teacher trainees in the middle of their training in physical education. University Sherbrook, 2014. [cited 2017 Nov 10]. Available from: http://hdl.handle. net/11143/5423

4. Perez-Roux T. Identity Construction of New Teachers: What Recognition of others to known as a Professional? Educations \& Research Journal, 2012; 7: 69-84.

5. Bali $\mathrm{N}$ et al. The Conceptions of Integration of Tunisian Physical Education Cooperative Teachers and Student Teachers. Creative Education, 2014; 5: 279-289.
6. Martineau S, Presseau A. The sense of professional incompetence of teachers early in their careers and support employability. Brock Education, 2003; 12: 2-6.

7. Zayed W, Bali N. Introduction of Student Teachers in Tunisian Secondary Schools: A Discourse Analysis of Cooperative Teacher. Creative Education, 2015a; 6: 359-368.

8. Carlier G. Supervise trainees in physical education: guidelines for a function in the process of professionalization. Belgium: Catholic University of Louvain; 2002.

9. Maela P. Autour du mot accompagnement. Recherche et formation, 2009; 62: 91-107.

10.Melki H, Bouzid MS, Haweni A, Fadhloun M, Mrayeh M, Souissi N. Formative assessment: exploring tunisian cooperative teachers practices in physical education. Pedagogics Psychology Medical-Biological Problems of Physical Training and Sports. 2017;21(5):227-235. doi:10.15561/18189172.2017.0505

11.Kosnik C. It is not just practice: Conflicting goals, unclear expectations. In: F.J, Benson \& C. Riches (dir.), Engaging in Conversations about Ideas in Teacher Education. New York: Falmer Press; 2009. P. 65-71. 
12.Desbiens JF, Borges C, Spallanzani C. I harm to my internship: problems and issues of practical training in teaching. Montréal, Québec: PUQ; 2012.

13.Chaliès S, Durand M. Summary note the usefulness of tutoring in initial teacher training: Forms and devices of professionalization. Research and Training, 2000; 35: 145180.

14.Carlier G, Clerx M. The pleasure of participating in a training course. In: Carlier G, Borges C, Clerx M, Delens C, editors. Professional identity in physical education. Research in teacher training and didactics. Belgium: university press of Louvain; 2012. P. 23-41.

15.Boutin G, Camaraire L. Welcome and mentor a trainee. Practical guide for the teacher-trainer. Montréal, Québec: News Editions; 2001.

16.Faingold N. Training of trainers in the analysis of practices. Research and Training, 2006; 51: 89-104.

17. Boutet M, Rousseau N. The challenges of pedagogical supervision of internships. Montréal, Québec: PUQ; 2002.

18.Trohel et al. The dynamics of trainee-trainee interactions in situation of educational advice. Knowledge, 2004; 5: 119140.

19.Brau-Antony S, Mieusset C, Lenfant A, Miot C. Analyze the work of tutors of beginning teachers. Permanent Education, 2011; 186: 175-185.

20.Vandercleyen F, Delens C, Carlier G. Supervisory styles of training supervisors in physical education: taking into account the emotional experience of trainees during a postlesson interview. EJRIEPS, 2013;2:61-99.

21.Boutet M, Pharand J. Accompanying concentrated of trainees in teaching. Montréal, Québec: PUQ; 2008.

22.Rayou P, Ria L. Train new teachers. Around the statutes, organization and professional knowledge. Education and Societies, 2009; 1: 79-90.

23.Paquay L. Continuity and progress in research on teacher training. In train professional teachers. Superior Boeck, 2012; 4: 5-26.

24.Buyse E, Verschueren K, Doumen S, Van Damme J, Maes F. Classroom problem behavior and teacher-child relationships in kindergarten: The moderating role of classroom climate. Journal of School Psychology, 2008; 46: 367-391.

25.Hamre BK, Pianta RC. Can instructional and emotional support in the first-grade classroom make a difference for children at risk of school failure? Child Development, 2005; 76: 949-967.

26.Zayed W, Bali N, Souissi N, Desbiens JF. The Conception of Tunisian student teachers of the formative role of the cooperative teacher's. Creative Education, 2015b; 6: 10601075.

27.Monfette O, Grenier J. Identification of roles that s' attribute associate teachers paired with student teachers of physical education who developed their self-efficacy after an internship. Revue McGill Educational Sciences, 2014; 49: 113-130.

28.Ndoreraho JP, Martineau S. A problem of early career in teaching. Retrieved November 20; 2009.

29.Gaudreau N, Royer É, Beaumont C, Frenette É. Positive Management of Classroom Situations: A model of on-the-job training to help elementary school teachers prevent difficult student behaviors. Childhood in difficulty, 2006; 1: 85-115.

30.Gilbert MC, Education EPE. An attempt at understanding the psychological suffering of teachers: a psycho-dynamic reading of work (Doctoral dissertation). Laval University; 2012.

31.Houlfort N, Sauvé F. Psychological health of teachers of the Autonomous Federation of Education. School of Public Administration; 2010.

32.Doudin PA, Curchod-Ruedi D, Lafortune L, Lafranchise N. The psychosocial health of teachers. Montréal, Québec: PUQ; 2011.

33.Bauer J, Unterbrink T, Hack A, Pfeifer R, Bulh-Griebhaber V, Muller U, Wesche H, Fromhold M, Seibt R, Scheuch $\mathrm{K}$, Wirsching M. Working conditions, adverse events and mental health problems in a sample of 949 German teachers. International Archive of Occupational and Environmental Health, 2007; 80: 442-449.

34.Mukamurera J. The dropping out of teachers. You have to sound the alarm. [cited 2011 July 26]. Available from: http:// cbcsq.qc.net/sites/1673/documents/secteurs/entrevue_j_ moukamouderas.pdf

35.Ingersoll RM, Smith TM. The wrong solution to the teacher shortage. Educational Leadership, 2003; 60(8): 30-33.

36.Parmentier C. The essence of the training. Paris, France: Organization Editions; 2003.

37.Rajuan M, Beijaard D, Verloop N. The role of the cooperating teacher: bridging the gap between the expectations of cooperating teachers and student teachers. Mentoring \& Tutoring: Partnership in Learning, 2007;15:223-42. doi:10.1080/13611260701201703.

38.Gold Y. Beginning teacher support. Attrition, mentoring, and induction. In: Sikula, J., Buttery, T. J. \& Guyton, E. (editors), Handbook of Research on teacher Education. Second Edition. New York: Macmillan Library; 1996. P. 548-594. 
Information about the authors:

Wadii Zayed (Corresponding author) ; http://orcid.org/0000-0001-9334-6964; zayed-wadii@hotmail.com; Higher Institute of Sport and Physical Education; Road of Tozeur 2100, Gafsa Tunisia.

Naila Bali; http://orcid.org/0000-0001-7751-6273; naila_bali@yahoo.fr; Higher Institute of Sport and Physical Education; Ksar Saïd 2010, Manouba Tunisia.

Nizar Souissi; http://orcid.org/0000-0003-1129-6727; n.souissi@yahoo.fr; Higher Institute of Sport and Physical Education; Ksar Saïd 2010, Manouba Tunisia.

Cite this article as: Wadii Zayed, Naila Bali, Nizar Souissi. Repercussions of behavior of cooperative teacher's on health and attractiveness of Tunisian student teachers. Physical education of students, 2018;22(2):104-111. doi:10.15561/20755279.2018.0208

The electronic version of this article is the complete one and can be found online at: http://www.sportedu.org.ua/index.php/PES/issue/archive

This is an Open Access article distributed under the terms of the Creative Commons Attribution License, which permits unrestricted use, distribution, and reproduction in any medium, provided the original work is properly cited (http://creativecommons.org/licenses/by/4.0/deed.en).

Received: 15.12 .2017

Accepted: 12.01.2018; Published: 27.04.2018 